\title{
Inovasi Olahan Lele oleh Kelompok Bunda Koja sebagai Strategi Pemberdayaan Masyarakat Area PT. Pertamina (Persero) Integrated Terminal Jakarta
}

\section{Catfish Product Innovation by Bunda Koja Community as Empowerment Strategy Around Operational Area PT. Pertamina (Persero) Integrated Terminal Jakarta}

\author{
Andri Akbar ${ }^{*}$, Ryan Hendra ${ }^{1}$, Anita Ervina ${ }^{2}$, Rida Aini Rahmawati ${ }^{2}$ \\ 1 PT. Pertamina (Persero) Integrated Terminal Jakarta, VWR2+X8M, RW.1, Koja, North Jakarta City, Jakarta 14220 \\ 2 Departemen Teknologi hasil Perikanan, Fakultas Perikanan dan Ilmu Kelautan, Institut Pertanian Bogor, \\ Kampus IPB Darmaga 16680. \\ *Penulis Korespondensi: andriebar@gmail.com \\ Diterima Agustus 2020/Disetujui Agustus 2021
}

\begin{abstract}
ABSTRAK
Pengetahuan mengenai makanan bergizi bagi balita serta kemampuan daya beli makanan bergizi dapat menjadi faktor penting dalam pola asuh balita. Kelurahan Rawa Badak Selatan (KRBS) merupakan salah satu kelurahan di Kecamatan Koja, Jakarta Utara yang didominasi balita dengan status gizi perlu ditingkatkan. CSR PT. Pertamina Integrated Terminal Jakarta mengusung kegiatan Serba Unsur Lele (Sule) sebagai strategi pemberdayaan masyarakat dengan membuat beragam inovasi produk olahan daging dan tulang ikan lele. Tujuan kegiatan ini adalah memberikan pengetahuan dan keterampilan kepada kelompok Bunda Koja termasuk ibu-ibu balita dalam mengolah produk inovasi lele serta membangun usaha yang terus berkembang. Sebagian produk yang secara rutin diberikan kepada beberapa balita diharapkan dapat memberikan dampak positif terhadap gizi balita. Pelaksanaan kegiatan dilakukan dengan metode pelatihan dan penerapan pendampingan. Rangkaian progam di antaranya pelatihan inovasi olahan lele, manajemen produksi olahan lele, dan pemasaran produk. Inovasi olahan lele yang dikembangkan meliputi nugget, abon, dan stik daging lele. Tulang lele diolah menjadi kerupuk, keripik tempe, dan biskuit tulang ikan. Produk abon, nugget, kerupuk, dan keripik tempe telah melalui tahap produksi dan pemasaran. Kegiatan ini berhasil memberikan dampak positif, yaitu kelompok Bunda Koja terutama ibu-ibu balita dapat merasakan adanya tambahan penghasilan dari usaha olahan lele. Inovasi produk olahan lele yang kemudian akan lebih banyak dikembangkan diharapkan menjadi bisnis, sehingga dapat memberikan dampak positif bagi perekonomian kelompok Bunda Koja, ibu-ibu balita, dan masyarakat sekitarnya.
\end{abstract}

Kata kunci: balita, makanan bergizi, program sule

\begin{abstract}
Knowledge about food nutrition for toddlers and the ability to buy nutritious food are important factors in toddlers parenting. Kelurahan Rawa Badak Selatan (KRBS) is one of area in Koja Subdistrict, North Jakarta which dominated by toddlers whose nutritional status needs to be improved. CSR PT. Pertamina Integrated Terminal Jakarta carried out the Serba Unsur Lele (SULE) program as a community empowerment strategy by create various product innovations from catfish and catfish bone by-product. The aim of this activities is Bunda Koja community, including mothers of toddlers, are able to improve the knowledge and skills of catfish products processing and build a growing business, some products that routinely given to toddlers are expected to give a positive impact for toddler nutrition. This program consisted of training and the application of mentoring. The series of programs include training on catfish products innovation training, management of catfish production, and product marketing. The innovations been developed for production is nuggets, abon, and catfish stick. Catfish bones by- product are processed into crackers, tempe chips, and fish bone biscuits. Abon, nuggets, crackers and tempeh chips have been through the production and marketing stages. This activity succeeded in having a positive impact especially for mothers of toddlers, could receive the additional income from the catfish product business. The more catfish products innovation which will be developed is expected to become a business so that it can have a positive impact on the economy of the Bunda Koja community, mothers of toddlers, and the surrounding community.
\end{abstract}

Keywords: nutritious food, sule program, toddlers 


\section{PENDAHULUAN}

Kelurahan Rawa Badak Selatan (KRBS) adalah salah satu kelurahan di Kecamatan Koja, Jakarta Utara yang memiliki kelompok umur balita terbesar kedua, sebanyak 5.304 jiwa (Tan 2020). Berdasarkan pernyataan Kepala Puskesmas Kecamatan Koja, KRBS termasuk salah satu kelurahan yang didominasi oleh tingkat status gizi balita yang perlu ditingkatkan. Peran ibu sebagai pengasuh serta pengetahuan gizi berpengaruh besar terhadap pertumbuhan balita dan menjadi salah satu faktor yang dapat memengaruhi status gizi balita (Rahma \& Nadhiroh 2016). Pengetahuan gizi ibu yang kurang memiliki hubungan dengan kasus balita gizi kurang (Ningsih et al. 2015).

Kondisi sosial ekonomi memiliki pengaruh pada konsumsi pangan rumah tangga yang berdampak pada status gizi anggota keluarga terutama balita (Riyadi et al. 2006). Faktor sosial ekonomi di antaranya adalah tingkat pendidikan, jenis pekerjaan, dan pendapatan dapat memengaruhi bentuk pola asuh ibu (Riyadi et al. 2006). Oleh karena itu, pendapatan dan pengetahuan orang tua balita di KRBS perlu ditingkatkan, sehingga diharapkan dapat mengubah pola asupan makanan balita, salah satunya dengan meningkatkan konsumsi olahan ikan.

Ikan lele (Clarias gariepinus) merupakan jenis ikan air tawar yang banyak digemari masyarakat karena rasanya enak dan memiliki kandungan gizi yang cukup tinggi. Kelebihan ikan lele adalah memiliki kemampuan beradaptasi yang cukup tinggi terhadap kondisi lingkungan dan pertumbuhan yang sangat cepat (Zulisyanto et al. 2016). Ikan lele dapat menjadi salah satu pilihan yang dapat diolah menjadi makanan praktis dan bergizi bagi balita. Lele utuh mengandung protein sebesar $12,82 \%$, lemak sebesar $3,70 \%$, abu sebesar 2,70\%, karbohidrat sebesar 2,60\%, dan kalsium sebesar 5,59\% (Handayani \& Kartikawati 2015). Daging lele mudah untuk diolah menjadi berbagai produk antara lain nugget, abon, dan stik.

Konsumsi kalsium masyarakat Indonesia ratarata hanya sebesar $254 \mathrm{mg}$ per hari. Kebutuhan kalsium yang dianjurkan menurut Peraturan Menteri Kesehatan No.7 tahun 2013 adalah 1.000-1.200 mg/hari (Kemenkes 2013). Konsumsi kalsium yang kurang dapat menyebabkan kerusakan gigi, gangguan pertumbuhan tulang, dan darah sukar membeku. Salah satu sumber kalsium yang dapat dimanfaatkan yaitu tulang ikan. Komponen utama penyusun tulang ikan lele di antaranya kalsium sebesar $21-25 \%$, fosfor sebesar 10-11\%, dan lemak sebesar 7\% (Bechtel et al. 2018). Bagian tulang lele yang tinggi kalsium, fosfor, dan mineral lainnya dapat dimanfaatkan menjadi produk seperti kerupuk, keripik tempe, dan biskuit. Pemanfaatan hasil samping berupa tulang lele menjadikan diversifikasi ikan lele yang zero waste. Diversifikasi olahan lele ini menjadi peluang bagi ibu-ibu balita dalam meningkatkan pendapatan disamping perbaikan pola asuh balitanya.

Program Serba Unsur Lele (Sule) merupakan program pemberdayaan dengan sasaran ibu-ibu balita dan kelompok Bunda Koja, mitra binaan Corporate Social Responbility (CSR) PT. Pertamina (Persero) Intergrated Terminal Jakarta dalam rangka meningkatan gizi balita dan pendapatan ibu-ibu balita KRBS. Ibu-ibu balita diedukasi mengenai gizi balita dan inovasi produk olahan lele, kemudian dilatih membuat produk olahan lele, hingga dapat memasarkan produk-produk olahan lele. Kegiatan ini bertujuan untuk memberikan pengetahuan dan keterampilan kepada kelompok Bunda Koja termasuk ibu-ibu balita dalam mengolah produk inovasi lele serta membangun usaha yang terus berkembang. Produk yang dibuat antara lain nugget, abon, dan stik dari daging lele, serta kerupuk, keripik tempe, dan biskuit dari tulang lele.

\section{METODE PELAKSANAAN KEGIATAN}

\section{Lokasi dan Partisipan Kegiatan}

Kegiatan ini dilaksanakan di Kelurahan Rawa Badak Selatan, Kecamatan Koja, Kota Jakarta Utara, DKI Jakarta. Kegiatan dimulai pada bulan September 2018-Mei 2021. Pelaksanaan kegiatan dilakukan dengan metode pelatihan dan penerapan pendampingan. Kelompok Bunda Koja yang berjumlah 10 orang dan ibu-ibu balita yang berjumlah 5 orang sebagai subjek dalam setiap aktivitas, didampingi pihak CSR PT. Pertamina (persero) Integrated Terminal Jakarta, akademisi IPB, dan puskesmas Kecamatan Koja.

\section{Bahan dan Alat}

Bahan dan alat yang digunakan dalam kegiatan ini meliputi: 1) Bahan dan alat untuk pelatihan inovasi olahan lele, yaitu materi pelatihan, LCD, laptop, dan peralatan menulis; 2) Bahan dan alat untuk membuat inovasi olahan lele, yaitu ikan lele, tepung beras, wortel, tepung panir, tempe, minyak sayur, bawang merah, 
bawang putih, ketumbar, lada, tepung tapioka, air, garam, tepung panir, lada, tepung terigu, wajan, panci, pisau, telur, gula merah, sereh, daun salam, sutil, mangkuk, timbangan digital, alas potong, wadah plastic, dan plastik zipplock; dan 3) Bahan dan alat untuk pendampingan manajemen produksi olahan lele dan pemasaran produk, yaitu LCD, laptop, buku, peralatan menulis, buku catatan, kertas, dan printer.

\section{Metode Pelaksanaan Kegiatan}

Rangkaian program meliputi pelatihan inovasi olahan lele, pendampingan manajemen produksi olahan lele, dan pendampingan pemasaran produk. Sistem pelatihan dan pendampingan dilakukan dengan praktik langsung, sehingga kelompok Bunda Koja dapat secara aktif memahami materi yang diberikan. Setelah kegiatan berlangsung, kelompok Bunda Koja juga dapat memberikan pengetahuan dan pengalaman selama pelatihan kepada masyarakat lingkungan sekitar.

Pelatihan inovasi olahan lele terdiri dari pemaparan materi oleh akademisi IPB mengenai kandungan gizi ikan lele, penanganan bahan baku ikan lele, dan tahapan proses pengolahan ikan lele. Bahan baku pembuatan inovasi olahan lele disiapkan oleh beberapa anggota kelompok Bunda Koja dan dibantu oleh pihak CSR PT. Pertamina (Persero) Integrated Terminal Jakarta. Produk inovasi olahan lele yang sudah dibuat bersama dengan semua partisipan, yaitu kelompok Bunda Koja, ibu-ibu balita, beberapa balita, dan pihak puskesmas Kecamatan Koja kemudian dapat langsung dikonsumsi dan dibawa oleh semua partisipan.

Pendampingan manajemen produksi olahan lele dilakukan pihak CSR PT. Pertamina (Persero) Integrated Terminal Jakarta bersama kelompok Bunda Koja. Kegiatan pendampingan dilakukan dengan melakukan kontrol dan evaluasi terhadap kegiatan produksi dan manajemen produksi mulai dari membuat Standar Operasional Produksi (SOP) agar kualitas produk selalu seragam, proses packaging (kemasan) hingga proses distribusi. Pihak CSR PT. Pertamina (Persero) Integrated Terminal Jakarta membantu penyediaan sarana rumah produksi dan prasarana yang telah terstandarisasi.

Pendampingan pemasaran produk dilakukan secara bertahap, penjualan produk awal secara off-line dilakukan terbatas kepada masyarakat sekitar lingkungan Kelurahan Rawa Badak Selatan, setelah beragam produk diproduksi dan mendapatkan izin Pangan Industri Rumah Tangga (PIRT) dari Dinas Kesehatahan, maka proses produksi dan distribusi akan dilakukan dengan skala yang lebih besar. Proses pemasaran secara langsung dilakukan dengan menawarkan produk untuk dimasukkan dalam expo, bazar, dan distribusi ke warung atau rumah makan. Kelompok Bunda Koja bersama dengan Pihak CSR PT. Pertamina (Persero) Integrated Terminal Jakarta akan melakukan pemasaran produk secara on-line melalui media sosial dan beragam marketplace.

\section{Metode Pengumpulan, Pengolahan, dan Analisis Data}

Pengumpulan data dilakukan dengan observasi, pengamatan, dan wawancara. Pengolahan data dilakukan menggunakan Microsoft Excel 2010. Analisis data secara kualitatif dengan penjabaran secara deskriptif menggambarkan tahapan pelaksanaan pemberdayaan ibu-ibu balita dan kelompok Bunda Koja sebagai kerja sama dari pihak CSR PT. Pertamina (Persero) Integrated Terminal Jakarta. Sumber informasi mengenai pelaksanaan kegiatan yang tertuang dalam penulisan makalah ini di antaranya adalah pihak CSR PT. Pertamina (Persero) Integrated Terminal Jakarta sebagai informan pelaksana program, pihak puskesmas Kecamatan Koja, ibuibu balita dan kelompok Bunda Koja sebagai penerima program.

\section{HASIL DAN PEMBAHASAN}

\section{Pelaksanaan Pelatihan Inovasi Olahan Lele}

Kegiatan pelatihan melibatkan akademisi IPB dibidang pengolahan hasil perairan. Proses dan teknik pembuatan beragam produk dilakukan sesuai dengan panduan materi yang telah disiapkan sebelumnya. Pelatihan inovasi olahan lele dibagi menjadi tiga sesi pertemuan. Sesi pertama adalah pembuatan nugget dan abon lele, sesi kedua adalah pembuatan stik lele, dan sesi ketiga adalah pemanfaataan hasil samping tulang lele menjadi produk kerupuk, keripik tempe, dan biskuit. Kegiatan ini dihadiri oleh ibu-ibu Bunda Koja, orangtua balita KRBS bersama balitanya dan pihak Puskesmas Kecamatan Koja. Materi yang dipaparkan dalam setiap sesi adalah edukasi mengenai kandungan gizi ikan lele, nilai ekonominya, pentingnya asupan gizi untuk balita, dan beragam produk olahan ikan lele. Luaran dari kegiatan ini adalah ibu-ibu balita dan ibu-ibu 
Bunda Koja memahami pentingnya asupan gizi dan cara membuat olahan dari ikan lele yang bergizi.

Pelatihan sesi pertama adalah pembuatan nugget dan abon lele pada bulan Maret 2018. Akademisi IPB memaparkan materi yang disiapkan yang ditampilkan dengan sebuah LCD, sehingga semua partisipan dapat menyimak dengan baik. Kegiatan dilanjutkan dengan praktik langsung pembuatan olahan ikan lele bersama akademisi IPB. Nugget lele dibuat dengan komposisi daging ikan lele yang lebih besar sebanyak $60 \%$, komposisi produk nugget dapat dilihat pada Tabel 1. Pembuatan nugget diawali dengan mencampurkan daging ikan lele dengan kuning telur, bawang putih halus, garam, dan gula menggunakan blender kemudian campuran tersebut ditambahkan wortel dan tapioka lalu diaduk hingga rata. Adonan nugget kemudian dikukus selama 30 menit. Adonan yang telah matang dipotong sesuai ukuran yang diinginkan, dilumuri tepung tapioka lalu dilumuri putih telur kemudian tepung panir. Nugget yang telah dilumuri tepung panir dapat langsung digoreng ataupun disimpan dalam freezer.

Produk yang dipraktikkan secara langsung selanjutnya adalah pembuatan abon lele. Proses pembuatan abon ikan lele diawali dengan menumis bumbu halus, kemudian serai, lengkuas, daun salam, daun jeruk, gula merah, dan santan. Daging lele yang telah dikukus dan disuwir kemudian dimasukkan ke dalam campuran bumbu lalu terus dimasak sampai kering kecokelatan, setelah matang dan sudah tidak panas, kemudian langsung dikemas dalam plastik. Komposisi produk abon lele dapat dilihat pada Tabel 2 . Selama kegiatan berlangsung semua partisipan dapat secara aktif mengajukan pertanyaan seputar nugget dan abon, setelah itu semua partisipan dapat mencicipi dan membawa produk yang sudah dibuat.

Selama kegiatan pelatihan berlangsung antusiasme partisipan cukup baik, melalui sesi diskusi banyak pertanyaan yang disampaikan terkait materi, rasa keingintahuan akan ikan lele dan olahannya serta peluang bisnisnya. Kelompok Bunda Koja beserta ibu-ibu balita dapat memeroleh pengetahuan baru seputar pembuatan nugget dan abon lele.

Pelatihan sesi kedua adalah pembuatan stik ikan lele pada Februari 2019. Pemaparan materi seputar olahan ikan dan kandungan gizinya ditampilkan dalam LCD yang disiapkan oleh akademisi IPB. Kegiatan dilanjutkan dengan demonstrasi pembuatan stik ikan lele secara
Tabel 1 Komposisi produk nugget lele

\begin{tabular}{lrr}
\hline $\begin{array}{l}\text { Bahan pembuatan } \\
\text { nugget }\end{array}$ & $\begin{array}{c}\text { Jumlah } \\
(\mathrm{g})\end{array}$ & $\begin{array}{c}\text { Komposisi } \\
(\%)\end{array}$ \\
\hline Daging ikan lele & 330 & 60,0 \\
Tepung panir & 80 & 14,5 \\
Telur & 50 & 9,1 \\
Wortel & 50 & 9,1 \\
Tepung sagu & 20 & 3,6 \\
Bawang putih & 5 & 0,9 \\
Bawang merah & 5 & 0,9 \\
Gula & 5 & 0,9 \\
Garam & 3 & 0,5 \\
Lada & 2 & 0,4 \\
\hline
\end{tabular}

Tabel 2 Komposisi produk abon lele

\begin{tabular}{lrr}
\hline $\begin{array}{l}\text { Bahan pembuatan } \\
\text { abon lele }\end{array}$ & $\begin{array}{c}\text { Jumlah } \\
(\mathrm{g})\end{array}$ & $\begin{array}{c}\text { Komposisi } \\
(\%)\end{array}$ \\
\hline Daging ikan lele & 300 & 64,8 \\
Santan & 60 & 13,0 \\
Bumbu halus & 30 & 6,5 \\
Gula merah & 30 & 6,5 \\
Minyak sayur & 20 & 4,3 \\
Garam & 10 & 2,2 \\
Serai & 5 & 1,1 \\
lengkuas & 3 & 0,6 \\
Daun salam & 3 & 0,6 \\
Daun jeruk & 2 & 0,4 \\
\hline
\end{tabular}

langsung oleh akademisi IPB (Gambar 1). Partisipan kemudian langsung mempraktikan kembali sesuai apa yang sudah dipaparkan dan langsung bisa mencoba hasil produk stik ikan yang dibuat.

Pembuatan stik lele diawali dengan proses blender daging lele. Daging lele yang lumat, telur, dan minyak kemudian dimasukkan kedalam campuran tepung terigu, tepung sagu, garam, gula, dan merica. Campuran diaduk, kemudian diuleni hingga kalis. Adonan kalis dicetak menjadi bentuk stik menggunakan pasta maker. Stik selanjutnya digoreng dengan minyak panas. Gambar 2 menunjukkan produk olahan daging ikan lele.

Pelatihan sesi ketiga dilaksanakan pada November 2019, yaitu pemanfaataan hasil samping tulang lele menjadi produk kerupuk, keripik tempe, dan biskuit. Pemaparan materi disampaikan oleh akademisi IPB, yaitu menjelaskan mengenai tulang ikan pada proses produksi pada nugget, abon, dan stik sebelumnya menjadi hasil samping yang belum dimanfaatkan padahal terdapat kandungan kalsium dan fosfor yang tinggi. Tulang dan kepala ikan lele memiliki kandungan kalsium sebesar 9,35\% lebih tinggi dibandingkan daging lele yang hanya sebesar $0,65 \%$. Selain kalsium, tulang ikan lele 


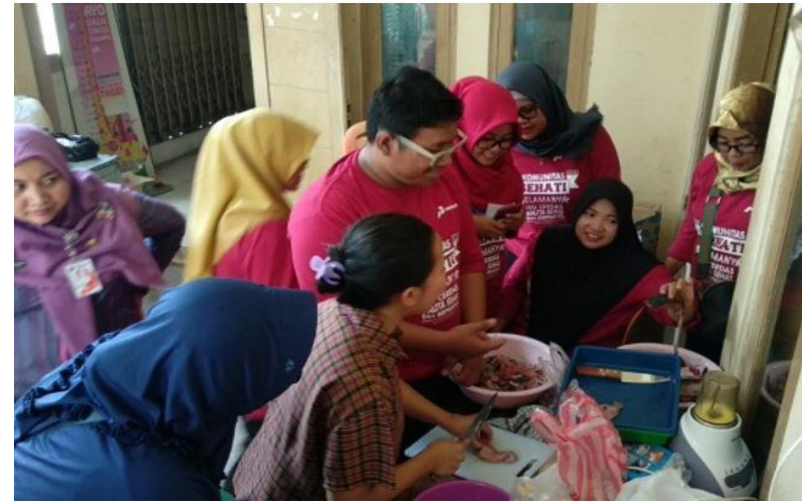

a

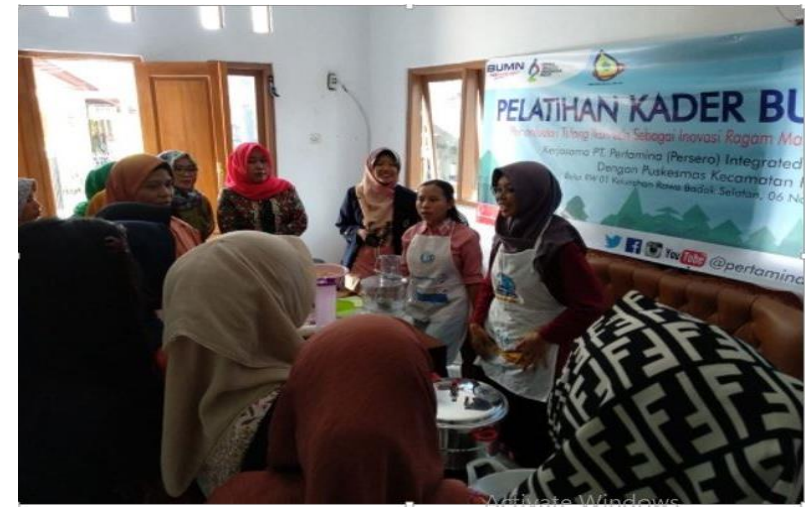

b

Gambar 1 a dan b Pelatihan pembuatan olahan ikan lele.

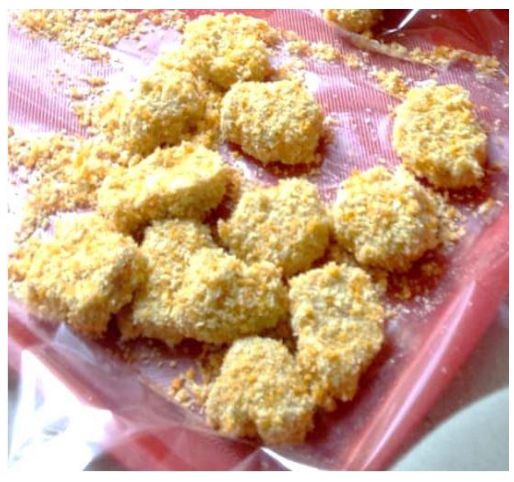

a

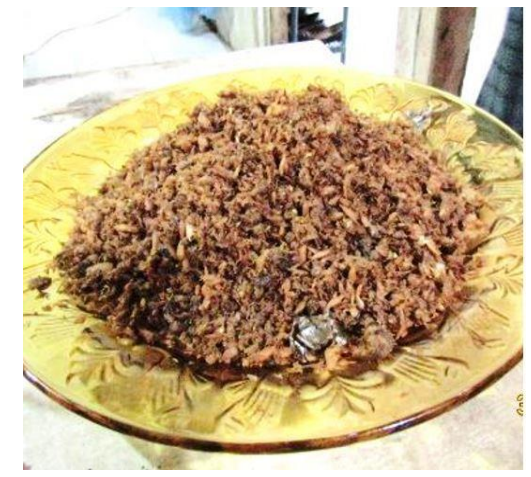

b

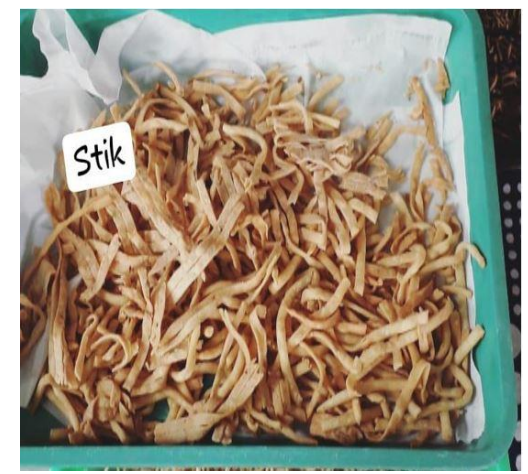

C

Gambar 2 Produk olahan daging ikan lele: a) nugget; dan b) abon; c) stik.

mengandung fosfor, magnesium, kalium, dan natrium (Handayani \& Kartikawati 2015). Mineral-mineral tersebut sangat dibutuhkan untuk pertumbuhan balita. Pemanfaatan tulang ikan diinisiasi dengan tingkat konsumsi kalsium yang kurang, sumber kalsium umumnya diperoleh dari susu sapi yang belum bisa banyak dijangkau oleh kalangan ekonomi kebawah.

Kegiatan selanjutnya adalah praktik langsung pembuatan produk kerupuk, keripik tempe, dan biskuit. Sebelumnya, tulang dan kepala ikan lele harus direbus dengan panci bertekanan tinggi selama dua jam. Proses perebusan tersebut dapat membuat tulang menjadi lunak sehingga mudah diaplikasikan pada berbagai produk. Pembuatan biskuit dilakukan dengan mencampurkan tepung, gula, ubi kuning, dan tulang lele. Pemanggangan biskuit dilakukan dengan oven selama sekitar 30 menit.

Pembuatan kerupuk tulang dilakukan dengan mecampurkan tulang lele yang telah dihaluskan dengan tepung tapioka, bumbu, dan rempah. Komposisi bahan produk keripik tempe tulang lele terlihat pada Tabel 3. Adonan kerupuk lalu direbus hingga matang, kemudian dipotong tipis, setelah itu dikeringkan dengan sinar matahari. Kerupuk yang telah kering kemudian digoreng dalam
Tabel 3 Komposisi produk keripik tempe tulang lele

\begin{tabular}{lcc}
\hline $\begin{array}{c}\text { Bahan pembuatan } \\
\text { keripik tempe tulang } \\
\text { lele }\end{array}$ & $\begin{array}{c}\text { Jumlah } \\
(\mathrm{g})\end{array}$ & $\begin{array}{c}\text { Komposisi } \\
(\%)\end{array}$ \\
\hline Tempe & 500 & 57,0 \\
Minyak sayur & 177 & 20,0 \\
Tepung beras & 100 & 11,0 \\
Tulang lele & 30 & 3,0 \\
Bawang merah & 30 & 3,0 \\
Tapioka & 20 & 2,0 \\
Bawang putih & 20 & 2,0 \\
Garam & 3 & 0,3 \\
Lada & 1 & 0,1 \\
\hline
\end{tabular}

minyak, setelah matang kerupuk dimasukkan kedalam wadah tertutup. Pembuatan keripik tempe dilakukan dengan menambahkan tulang ikan kedalam adonan tempe, lalu digoreng hingga matang.

Produk kerupuk, keripik tempe, dan biskuit (Gambar 3) yang telah dibuat dapat langsung dicoba oleh semua partisipan. Hasil yang diperoleh dari kegiatan ini, beragam produk yang telah dibuat dengan komposisi yang padat gizi dan dapat disukai oleh banyak kalangan. Produk nugget dan biskuit lebih banyak dicicipi oleh anak-anak dan balita. Produk abon, kerupuk, dan keripik tempe lebih banyak dicicipi oleh ibu-ibu. 


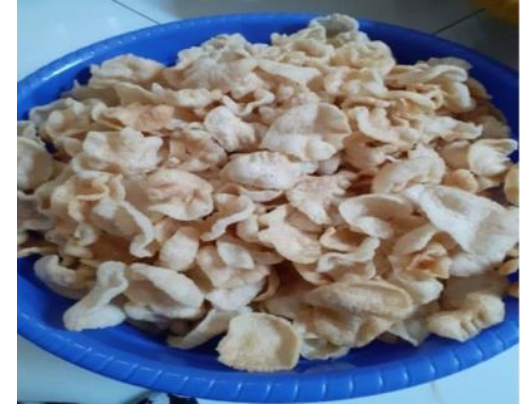

a

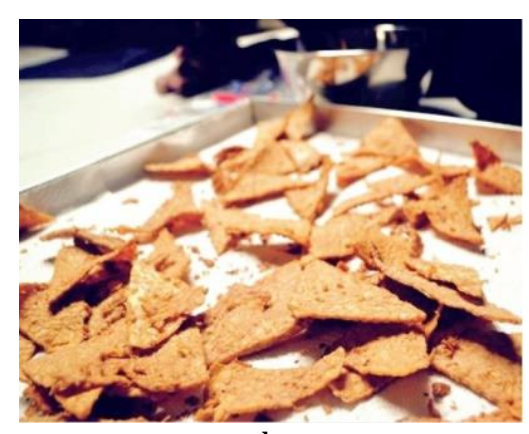

b

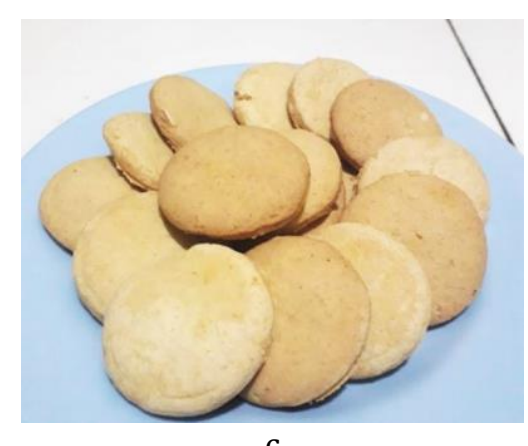

C

Gambar 3 Produk olahan tulang lele: a) kerupuk; b) keripik tempe tulang; dan c) biskuit.

\section{Pendampingan Manajemen Produksi Olahan Ikan Lele}

Pendampingan manajemen produksi dilakukan dengan memastikan proses tata kelola produksi yang baik, sehingga diperoleh produk dengan kualitas yang terstandar. Kegiatan pendampingan dilakukan dengan melakukan kontrol dan memberikan masukan terhadap kegiatan produksi dan manajemen produksi mulai dari membuat Standar Operasional Produksi (SOP) agar kualitas produk selalu seragam, proses kemasan, dan pengurusan izin Pangan Industri Rumah Tangga (PIRT).

Proses produksi olahan lele dilakukan oleh kelompok Bunda Koja dengan melibatkan ibu-ibu balita diawali dengan penyusunan SOP produksi serta penyusunan standar sanitasi dan higiene yang baik. Proses pengolahan ikan lele yang bersifat highly perishable sangat memperhatikan produksi rantai dingin (Cold Chain Production) sehingga setiap produk nugget setelah selesai produksi kemudian distribusi selalu dalam keadaan beku. Sanitasi dan higiene dilakukan dengan selalu mencuci tangan dengan sabun sebelum dan sesudah kegiatan produksi, menggunakan masker, dan sarung tangan untuk mencegah terjadinya kontaminasi. Peralatan dan tempat produksi selalu dalam keadaan bersih sesudah dan sebelum produksi.

Pelaksanaan kegiatan produksi juga diiringi dengan pendampingan manajemen keuangan sehingga kelompok Bunda Koja dan ibu-ibu balita mampu merencanakan wirausaha olahan daging dan tulang ikan lele secara berkelanjutan. Pendampingan proses kalkulasi harga pokok produksi (HPP) pada produk olahan lele meliputi perhitungan biaya habis pakai, biaya perlengkapan yang diperlukan, dan biaya penyusutan alat yang disesuaikan dengan kapasitas produksi. Pihak CSR PT. Pertamina (Persero) Integrated Terminal Jakarta memberikan pendampingan untuk pengemasan dan peralatan yang dibutuhkan selama proses produksi. Gambar 4

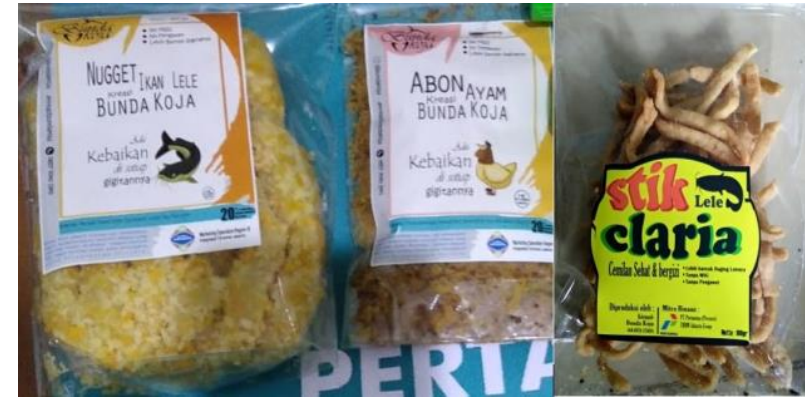

Gambar 4 Pengemasan produk-produk inovasi olahan lele kelompok Bunda Koja.

menunjukkan pengemasan produk-produk inovasi olahan lele kelompok Bunda Koja.

Kemasan (packaging) dan label merupakan faktor pendukung agar produk dapat disukai, dikenal, dan dikomersialkan dengan baik. Produk-produk hasil olahan tulang dan daging lele juga dikemas dengan plastik polyethylene (PE) untuk melindungi produk dari kontaminasi dan meningkatkan umur simpan produk. Produk nugget (ready to cook) dalam keadaan beku, produk abon, biskuit, keripik tempe tulang dan kerupuk dikemas dalam plastik zipplock.

Pihak CSR PT. Pertamina (Persero) Integrated Terminal Jakarta kemudian membantu penyediaan sarana rumah produksi yang telah terstandarisasi. Bunda Koja dapat dengan mandiri melakukan produksi dan mengemas produk sehingga siap dipasarkan. Produk abon, nugget, dan keripik tempe mulai tahun 2018 telah melalui tahap produksi yang dilakukan satu kali dalam seminggu. Sebagian produk akan diberikan kepada beberapa balita disekitar Kelurahan Rawa Badak Selatan sebagai makanan tambahan pada setiap bulan. Produk abon, nugget, dan keripik tempe yang padat gizi diharapkan mampu memberikan dampak positif bagi peningkatan gizi balita.

Puskesmas Kecamatan Koja mencatat pada semester pertama bulan Juni tahun 2018, persentase balita BGM (Bawah Garis Merah) sebanyak 1,8\%, yaitu sebanyak 22 balita gizi 
buruk dan gizi kurang menurut BB/U $(<-3$ SD s/d -2 SD) di wilayah Kelurahan Rawa Badak Selatan. Persentase ditimbang berat badannya 78\%, Persentase jumlah balita gizi buruk yang mendapatkan perawatan 100\% (Ulfa 2018).

Produk nugget lele yang diberikan kepada balita sebagai makanan tambahan setiap bulan menunjukkan perubahan peningkatan status gizi balita di Kelurahan Rawa Badak Selatan. Pada tahun 2018 setelah pemberian produk nugget secara rutin setiap bulan, terdapat perubahan peningkatan status gizi balita berdasarkan BB/TB dilihat dari sebelum perbaikan sangat kurus sebanyak 2 balita, kurus 20 balita, dan normal 0 balita. Sesudah perbaikan sangat kurus sebanyak 0 balita, kurus 5 balita, dan normal 17 balita (Gambar 5). Perbandingan tersebut sangat signifikan membedakan adanya perubahan status gizi balita di Kelurahan Rawa Badak Selatan (Ulfa 2018).

\section{Pemasaran Produk Olahan Ikan Lele}

Pendampingan pemasaran produk dilakukan secara bertahap, penjualan awal dilakukan terbatas pada masyarakat sekitar lingkungan Kelurahan Rawa Badak Selatan. Produk kreasi olahan lele Bunda Koja diperkenalkan secara offline dengan distribusi produk-produk Bunda Koja ke berbagai warung, gerai atau toko. Kelompok Bunda Koja juga melakukan audiensi dengan berbagai instansi seperti pihak keluarahan, Balai Pengawas Obat dan Makanan (BPOM), dan Walikota Jakarta Utara untuk dapat mengenalkan beragam produk Sule dan dampak positif bagi orangtua balita dan lingkungan sekitarnya.

Kegiatan ini memberikan dampak bagi peningkatan gizi dan sosioekonomi orangtua balita, melalui pelatihan produk olahan ikan lele yang bergizi, ibu-ibu balita dapat belajar memahami pentingnya makanan bergizi untuk balita dan inovasi-inovasi olahan dari ikan lele yang memiliki peluang bisnis. Produk olahan ikan yang berhasil dibuat oleh ibu-ibu balita sebagian kecil dibawa untuk dibagikan pada balitanya sebagai makanan pendamping nasi, sehingga secara tidak langsung berdampak terhadap perbaikan pola asuh balita. Selain itu, sebanyak 10\% yang diperoleh dari keuntungan pada setiap produksi juga akan akan diberikan untuk peningkatan gizi balita.

Produk yang mulai diproduksi pada tahun 2018 berdasarkan pernyataan kelompok Bunda Koja memberikan hasil keuntungan sekitar Rp 500.000 setiap bulan. Pada tahun 2019, setelah disiapkan sarana rumah produksi yang dibantu Pihak CSR PT. Pertamina (Persero) Integrated Terminal Jakarta, proses produksi menjadi bisa lebih banyak, keuntungan hasil produksi juga tiga kali lebih besar dibanding tahun sebelumnya (Gambar 6). Pada tahun 2020 kelompok Bunda

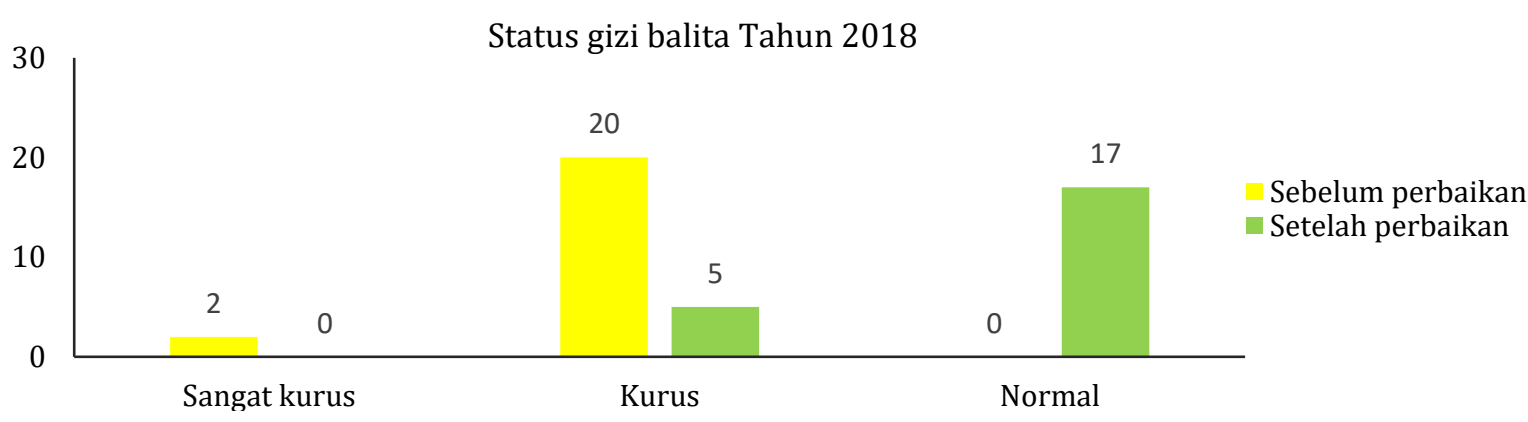

Gambar 5 Status gizi balita pada Tahun 2018.

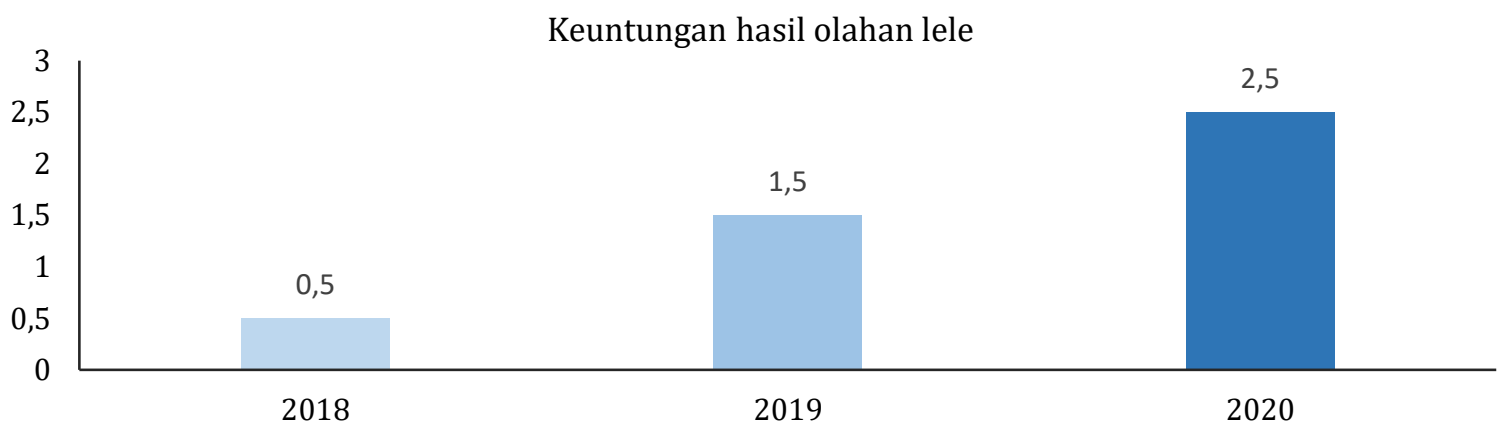

Gambar 6 Keuntungan hasil produksi olahan lele Bunda Koja. 
Koja telah mendapatkan izin PIRT dan telah melakukan penjualan secara on-line dimedia sosial dan marketplace.

Kegiatan ini berhasil memberikan dampak positif bagi penerima program terutama ibu-ibu balita KRBS. Menurut hasil wawancara terhadap salah satu penerima program, adanya program Sule ini dapat memberi tambahan penghasilan bagi ibu-ibu balita. "Sule bisa maju, berhasil, berkat ibu-ibu Bunda Koja sama pendamping CSR. Kalo semua ga ada semangat, ya gagal Sule ini. Sekarang dengan adanya SULE jadi diajarin bikin ini itu, terus juga bisa bantu balita yang kurang gizi, kita jadi kenal sama orang baru, kenal sama orang puskesmas. Toh hasilnya juga buat kita kalo ini Sule bisa laku di pasaran." (In, 50 tahun).

\section{SIMPULAN}

Program Sule telah berhasil memberikan pengetahuan dan keterampilan baru mengenai inovasi-inovasi produk olahan ikan lele kepada kelompok Bunda Koja termasuk ibu-ibu balita KRBS. Hasil proses produksi Sule yang secara rutin diberikan kepada balita berdampak positif terhadap peningkatan status gizinya. Peran CSR PT. Pertamina, akademisi IPB, dan Puskesmas Kecamatan Koja sangat berpengaruh terhadap perkembangan program ini. CSR PT. Pertamina berperan dalam pemberian dana stimulan serta pendampingan dan monitoring implementasi program Sule. Program Sule diharapkan dapat menjadi usaha produktif berkelanjutan perlu ditingkatkan kebersamaan, kerja sama, dan motivasi anggota program serta pengembangan kemitraan dengan pemerintah setempat dan stakeholders lainnya. Inovasi-inovasi produk dari ikan lele diharapkan terus berkembang, tidak hanya produk nugget, abon, stik, keripik tempe, dan kerupuk tulang ikan, olahan seperti biskuit tulang lele, brownies, pempek ikan lele, dan sebagainya dapat dikembangkan menjadi suatu usaha. Produk-produk inovasi olahan ikan lele ini sangat berpeluang untuk dikembangkan menjadi bisnis dan berpotensi meningkatkan perekonomian ibu-ibu balita dan masyarakat sekitarnya.

\section{DAFTAR PUSTAKA}

Bechtel PJ, Watson MA, Lea JM, Bett-Garber KL, Bland JM. 2015. Properties of bone from catfish heads and frames. Food Science and Nutrition. 7(4): 1396-1405. https://doi.org/ $10.1002 /$ fsn3.974

Handayani DIW, Kartikawati D. 2015. Stik lele alternatif diversifikasi olahan lele (Clarias sp.) tanpa limbah berkalsium tinggi. Jurnal Ilmiah. 4(1): 109-117.

[Kemenkes] Kementrian Kesehatan RI. 2018. Riset Kesehatan Dasar Tahun 2018.

[Kemenkes] Kementrian Kesehatan RI. 2013. Peraturan Menteri Kesehatan Republik Indonesia Tentang Angka Kecukupan Gizi Yang Dianjurkan Bagi Bangsa Indonesia Nomor 75 Tahun 2013.

Ningsih S, Kristiawati, Krisnana I. 2014. Hubungan perilaku ibu dengan status gizi kurang anak usia toddler. Jurnal Pediomaternal. 3(1): 58-65.

Rahma AC, Nadhiroh SR. 2016. Perbedaan sosial ekonomi dan pengetahuan gizi ibu balita gizi kurang dan gizi normal. Media Gizi Indonesia. 11(1): $\quad 55-60 . \quad$ https://doi.org/10. 20473/mgi.v11i1.55-60

Riyadi H, Khomsan A, Dadang S, Faisal A, Eddy S. 2006. Studi tentang status gizi pada rumah tangga miskin dan tidak miskin. Gizi Indonesia. 1(2006). https://doi.org/10. 25182/jgp.2006.1.1.23-28

Tan AN. 2020. Strategi Penguatan Modal Sosial dalam Pelaksanaan Program CSR-Serba Unsur Lele. [Skripsi]. Bogor (ID): Institut Pertanian Bogor.

Ulfa. 2018. Makalah Tenaga Kesehatan Kota Administrasi Jakarta Utara Tahun 2018.

Zulisyanto D, Riyadi PH, Amalia U. 2016. Pengaruh lama pengukusan adonan terhadap kualitas fisik dan kimia kerupuk ikan lele dumbo (Clarias gariepinus). Jurnal Pengetahuan dan Bioteknologi Hasil Perikanan. 5(4): 26-33. 